\title{
Zpráva z vědecké konference Ústavní kontinuita České republiky s československou tradicí
}

Ve dnech 10.-11. května 2018 se uskutečnila v Praze mezinárodní vědecká konference Ústavni kontinuita České republiky s československou tradicí.

Konference byla uspořádána Právnickou fakultou Univerzity Karlovy v rámci projektu Univerzita a republika (1918-2018) a programů Progres Q04 Právo v ménícím se světě a Progres Q05 Právní a společenské aspekty migrace a problémy postaveni menšin.

Slavnostní plenární zahájení konference se konalo v nádherných prostorách Vlasteneckého sálu starobylého Karolina, přičemž mezi př́tomnými byla kromě rektora Univerzity Karlovy, prof. MUDr. Tomáše Zimy, DrSc., jenž nad akcí převzal záštitu, řada čelných ústavních činitelů, jakož i představitelů právní vědy - tuzemské i zahraniční.

Účastníky konference za organizátory přivítal děkan Právnické fakulty Univerzity Karlovy, prof. JUDr. Jan Kuklík, DrSc. S krátkými proslovy vystoupili rektor Univerzity Karlovy, prof. Tomáš Zima, předseda Senátu Parlamentu ČR Milan Štěch, předseda Ústavního soudu dr. Pavel Rychetský a velvyslanec Slovenské republiky v České republice dr. Peter Weiss.

Poté zazněly stě̌žjní referáty, které ústřední téma konference, tj. otázku kontinuity a diskontinuity české státnosti, představily v různých pohledech. Prorektor Univerzity Karlovy a současně vedoucí katedry ústavního práva a katedry teorie práva Právnické fakulty Univerzity Karlovy, prof. JUDr. Aleš Gerloch, CSc., ve svém př́spěvku Ústavní systém České republiky: tradice, změny, perspektiva nastínil základní atributy ústavního systému České republiky, jeho normativní nastavení v ústavním pořádku a dynamiku jeho funkčních parametrů. Zvláštní pozornost věnoval i rozměrům kontinuity a diskontinuity s československou tradicí. Stranou jeho pozornosti však nezůstaly ani nově se vynořující faktory, jež jsou způsobilé do budoucna ovlivnit funkčnost tuzemského ústavního systému.

Děkan Právnické fakulty Univerzity Karlovy a vedoucí Ústavu právních dějin téže fakulty, prof. JUDr. Jan Kuklík, DrSc., ve svém referátu Ústavní systém České republiky $z$ historické perspektivy poutavě přiblížil proces zřízení samostatného československého státu. Upozornil, že tento akt vyvolal potřebu zodpovězení řady otázek, které v mnoha ohledech ovlivnily podobu naší státnosti do dnešní doby. V prvních dnech existence nového státu se mj. rozhodovalo o státoprávním uspořádání, o republikánské formě a kontinuitě a diskontinuitě s Rakouskem-Uherskem.

Stranou však nezůstaly ani recentní milníky ve vývoji České republiky. Proděkan Právnické fakulty Univerzity Karlovy a současně vedoucí její katedry evropského práva, prof. JUDr. PhDr. Michal Tomášek, DrSc., přiblížil, dílem i z autopsie, poměrně spletitou 
počáteční fázi cesty, která předcházela přijetí České republiky do evropských struktur, a to ve svém referátu na téma Ústavní kontinuita ČSFR a ČR v relaci k členství v Evropské unii.

Druhý den rokování konference pokračovala na půdě Právnické fakulty Univerzity Karlovy. Ve třech paralelně probíhajících sekcích zaznělo 50 příspěvků tematicky spadajících do oblasti práva ústavního, mezinárodního, teorie práva a právních dějin.

V první sekci, Ústavněprávní instituty v proměnách času, jak naznačuje její název, převážně zazněly příspěvky nastiňující vývoj, ne vždy přímočarý a bezproblémový, různých ústavněprávních institutů v průběhu minulých sta let. Dr. Jindřiška Syllová přiblížila prvorepublikové postavení poslance a poslaneckého klubu a jejich odraz do současnosti. Doc. Jan Wintr pak na toto téma navázal, kdy představil prvorepublikové kořeny české parlamentní kultury. Na moc výkonnou se zaměřily př́spěvky dr. Miloše Matuly (Kontinuita a diskontinuita ústavní regulace výkonné moci v podmínkách ČR), dr. Vladislava Vnenka (Úřednické vlády a institut důvěry v ústavním systému ČR) a dr. Jana Kudrny (Výkon státní moci v mimořádných situacích). Velkou pozornost vzbudily i referáty zkoumající roli a postavení hlavy státu, a to nejenom tuzemské. Prof. L'ubor Cibulka analyzoval stávající postavení prezidenta Slovenské republiky prizmatem prvorepublikové úpravy. Prof. Jan Kysela se zaměřil na kontrasignaci aktů prezidenta republiky v proměnách času. Dr. Jiř́ Šouša rozšíril diskuzi o problematiku amnestie. Doc. Helena Hofmannová a Mgr. Karel Řepa se zamýšleli nad tím, zda je prezident garantem stability parlamentní republiky. Rovněž soudní moc nezůstala nepovšimnuta. Dr. Jana Ondřejková nastínila rozhodovací činnost Ústavního soudu ČSFR jako možný inspirační zdroj současného českého Ústavního soudu. Dr. Michal Šejvl pak hledal paralelu mezi judikaturou Nejvyššího správního soudu z let 1920-1948 a stávajícím prŕístupem soudů k rozhodování o lidských právech. Dr. Daniel Pal'ko srovnával diskontinuitu ve způsobech výběru a jmenování soudců československého, českého, slovenského a rakouského ústavního soudu. Velká část referentů se však zaměřila i na různé lidsko-právní otázky v časových souvislostech. Státní občanství si zvolil dr. Jiř́i Hřebejk, svobodu pohybu doc. Jan Štemberk, azyl a migraci pak dr. Kamil Nedvědický. Dr. Josef Mrázek a dr. René Petráš se věnovali různým aspektům problematiky menšin. Tematicky blok uzavřel Mgr. Karel Světnička příspěvkem věnovaným úloze spolků v ústavní kontinuitě ČR s československou tradicí.

Druhá sekce, Ústavni systém z historické perspektivy, byla primárně zaměřena na přiblížení prvních let existence samostatného československého státu. Prof. Karel Malý nastínil proměny monarchického ústavního a právního pořádku po vzniku ČSR. Doc. Vladimír Kindl představil konstituční oporu soudní moci do nabytí účinnosti ústavní listiny z roku 1920. Doc. Ondřej vnesl téma mezinárodního postavení první republiky, a to se zvláštním zřetelem na její bezpečnostní zájmy. Problematika mezinárodního práva byla příznačná i pro dr. Sandru Brožovou, která se prizmatem tohoto oboru zamýšlela nad prínosem prof. Antonína Hobzy k formování československých ústavních tradic. Dr. Jan Pinz načrtl kritiku vývoje československé a české ústavnosti, a to zejména optikou tzv. Londýnské koncepce reformy ústavního řádu Československé republiky. Mgr. Jan Kober se zaměřil na záměr přepsat ústavní listinu z roku 1920 a ideový program domácího odbojového hnutí PVVZ. Doc. Pavel Maršálek obohatil zasedání o téma sudetoněmeckého revanšismu. Dr. Stanislav Polnar vystoupil s př́íspěvkem věnovaným politickým a právním základům československé branné povinnosti. V rámci druhé sekce se ale rovněž diskutovala problematika zakotvení svobody tisku po vzniku ČSR (doc. Ladislav Soukup), volební právo 
z roku 1920 (doc. Pavel Mates), právní a ekonomické souvislosti zrodu československé a české měny (doc. Ilona Bažantová), jazyková (dis)-kontinuita textů tuzemských ústav (dr. Peter Brezina) či třeba tradice publikace práva a sbírky právních předpisů (dr. Lukáš Králík). Ze strany Mgr. Martina Kolouška zazněla kritika nedostatku filozofické koncepce Ústavy ČR. Doc. Vladimírem Zoubkem byla představena geopolitika českého státu v měnícím se světě.

$\mathrm{V}$ rámci třetí sekce, Ústavněprávni kontinuita a recentní problémy, byl celý jeden blok vyhrazen teoretickému uchopení konceptu právní kontinuity a diskonutinuity, a to se zvláštním zřetelem na české reálie. V rámci toho bloku se svými příspěvky vystoupili prof. Václav Pavlíček, dr. Jan Bárta, dr. Jaroslav Kuba a dr. Jan Tryzna. Rozsáhle byla diskutována i problematika př́mé formy demokracie. Dr. Cyril Svoboda se zamýšlel nad potřebou ústavního zákona o referendu. Prof. Vladimír Čechák analyzoval různé formy demokracie, jejich úprav, a to ve snaze posoudit jejich slučitelnost s ústavním pořádkem České republiky. Právní regulaci referenda na Slovensku přiblížila doc. Gabriela Dobrovičová s doc. Alenou Krunkovou. Obecnější srovnání státoprávních kategorií ve vývoji České republiky na straně jedné a Slovenské republiky na straně druhé po roce 1992 nabídla doc. Jana Reschová. Stranou pozornosti však nezůstaly ani recentní ústavněprávní změny v Polsku, které prezentovali dva významní představitelé polské právní nauky. Jmenovitě prof. Marian Grzybowski nastínil další možný osud polské Ústavy z roku 1997. Prof. Krzysztof Skotnicki pak detailně přiblížil proměny soudní moci, ke kterým v Polsku dochází od roku 2015. V přehledu témat nelze nezmínit ani př́spěvek dr. Pavla Zářeckého, jenž provedl historický výklad ústavního zakotvení územní samosprávy. Byly nastíněny i různé aktuální ústavněprávní otázky: Doc. Eduard Burda se zamýšlel nad tím, zda charakter ústavního práva není ovlivněn určitou ideologií a konkrétními právními zájmy. Mgr. Juraj Juhás představil výsledky empirické analýzy rozhodovací činnosti Ústavního soudu ČR v rámci výkonu abstraktní kontroly ústavnosti. Dr. Ján Štiavnický obohatil konferenci o výklad § 171 ods. 3 Ústavy z roku 1948, který stanovil, že ústavní zákony, jiné zákony a další právní předpisy, jejich výklad a používaní musí být v souladu s Listinou základních práv a svobod. Dr. Petr Čechák nastolil téma př́ipustnosti prolomení tzv. klauzule věčnosti v ústavách demokratických právních států. Dr. Jan Šmíd a dr. Katarzyna Žák Krzyžanková pak ve svých prŕspěvcích pozornost účastníků zaměřili na volební problematiku.

Přednesené př́íspěvky přinesly řadu nových poznatků a neotřelých pohledů na uplynulé století vývoje československé a české státnosti. Ve svém souhrnu pak nepochybně přispěly k důstojnému prripomenutí i oslavě vzniku Československé republiky.

doi: 10.14712/2464689X.2018.59

Katarzyna Žák Krzyžanková 